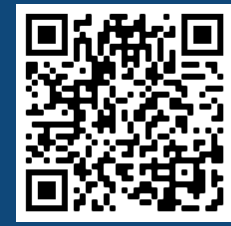

Keywords:

Commercial species

Dendrometry

Forest management

Tropical forest

Volumetric models

Historic:

Received 17/04/2020

Correspondence: misael02freitas@gmail.com
Misael Freitas dos Santos ${ }^{1 a+}$, Afonso Figueiredo Filho ${ }^{1 b}$, João Ricardo Vasconcellos Gama ${ }^{2 a}$, Fabiane Aparecida de Souza Retslaff'c; Daniele Lima da Costa ${ }^{\text {Id }}$

\section{SPECIES-SPECIFIC EQUATIONS: GREATER PRECISION IN COMMERCIAL VOLUME ESTIMATION IN MANAGED FORESTS IN THE AMAZON}

SANTOS, M. F. dos; FIGUEIREDO FILHO, A.; GAMA, J. R. V.; RETSLAFF, F. A. de S.; COSTA, D. L. da. Species-specific equations: Greater precision in commercial volume estimation in managed forests in the amazon. CERNE, v. 26, n. 3, p.3।5-330, 2020.

\section{HIGHLIGHTS}

Species-specific equations are more precise for volume estimation than generic equations.

Generic equations can produce large tendencies to under- and overestimate volumes of individual species.

Specific equations reduce underestimation of volume for species that normally possess large trees.

Single input species-specific equations are valid and recommended for use in the Tapajos National Forest (TNF).

\section{ABSTRACT}

The objective of this study was to analyze the performance of species-specific equations (SSEs) concerning generic ones in Annual Production Units (GEAPUs) and in a Forest Management Area (GEFMA) in the Brazilian Amazon. A total of 29, II 9 trees from 43 species were inventoried, harvested, and volumetric measurements were taken in ten APUs, with $10 \%$ of this total being separated for validation and comparison of the selected equations. After selection and validation of the equations (GEFMA, GEAPUs and SSEs) they were compared using precision statistics, by contrasting estimated and observed volumes and by residual analysis. Precision statistics were clearly lower for the SSEs. Trend lines near the average observed volume were shown for the SSEs when the estimates were contrasted with the observations. The residuals generated by the SSEs were smaller and statistically different than those of GEFMA and GEAPUs for the majority of cases. The most important commercial species (M. huberi) had its volume overestimated by 10.6, 9.3 and 3.0\% when the GEFMA, the GEAPUs, and the SSEs were applied, respectively. Among the species that generally had very large trees, $H$. petraeum had its volume underestimated by $15.7,16.6$ and $4.4 \%$ by the GEFMA, GEAPUs and SSEs, respectively. The greater precision of the SSEs is reflected in better forest management planning decisions with respect to operational and economic aspects. These results show that besides being statistically valid, the SSEs are recommended for obtaining more precise estimates of commercial volume, especially since there is a great demand for reliable estimates for each individual species in forest management areas in the Amazon.
IUniversity of the Midwest of Parana, Irati, Parana State, Brazil, ORCID: 0000-0002-6388-7679a, 0000-000 I-9965785 I b, 0000-0003-4025-9562c, 0000-0002-I 685-7864

${ }^{2}$ University of Western Para, Santarem, Para, Brazil, 0000-0002-3629-3437 


\section{INTRODUCTION}

Forest management requires criterious planning to be conducted and estimation of commercial volumetric production is crucial to this process (Ribeiro et al., 20I4; Tonini and Borges, 2015). In the Brazilian Amazon, the need for reliable estimates is gaining in importance because the estimated volumetric stock is one of the principal pieces of information required by public agencies responsible for forest management in order to emit annually the Logging Authorization (AUTEX) certificate to forest management companies operating in native forests (Brasil, 2009).

Estimates are primarily made using volume equations, and these can be generic or specific. A generic volumetric equation is constructed using data collected from various tree species, while a species-specific equation refers to an allometric equation developed from observations collected from a single tree species (Kora et al., 20l8).

In the Brazilian Amazon generic equations developed based on an entire Forest Management Area (FMA) are commonly used, such as those developed by Rolim et al. (2006), Colpini et al. (2009), Thaines et al. (20I0), Barreto et al. (20/4), Silva and Santana (20/4), Gimenez et al. (20I5) and Tonini and Borges (20I5). In the Tapajos National Forest (TNF), initiatives promoted by a forest management company have enabled the use of generic equations for Annual Production Units (APUs), and these equations are therefore restricted to a specific area. Although these equations have been compared to a generic equation used in the TNF (Gomes et al., 2018), there is still a need for comparisons with equations that are specific for species.

Gains in precision have been observed from the use of equations developed for smaller areas, possibly as a function of a reduction in environmental variation (Mauya et al., 2014; Vibrans et al., 20I5; Kachamba and Eid, 2016; Gomes et al., 2018). However, in natural tropical forests, the great heterogeneity in species' composition and structure, even in small areas, represents an important challenge for the development of volumetric equations (Akindele and LeMay, 2006; Soares et al., 20I I). According to the authors cited in the previous sentence, data stratification by species represents one of the principal alternatives to obtain more precise volume estimates.

It is important to consider that according to the Logging Authorization (AUTEX), the maximum volume authorized for harvesting is specific for species (Brasil, 2009). Variation in these volumes depends on, among other factors, the estimated production presented by the forest management company to the environmental regulation agency. In this way, precise estimates must be conducted for each individual commercial species. The more accurate the estimates for each species, the less will be the discrepancy between authorized volume and that of the harvest.

Although some studies have developed equations specific for some Amazonian commercial species (Lima et al., 20I4; Ribeiro et al., 20I4; Cysneiros et al., 2017; Santos et al., 2019), for the majority of species that are currently managed, specific equations have not been tested. Furthermore, in this region species-specific equations have rarely been compared to generic ones, as has been done in other regions and continents (Guendehou et al., 2012; Vibrans et al., 2015; Goussanou et al., 2016; Kora et al., 2018). Therefore, besides developing speciesspecific equations that are appropriate for Amazonian species, it is necessary to evaluate their performance in relation to generic equations.

In this context, objective of this study was to analyze the performance of species-specific commercial volume equations in relation to generic ones in a FMA and by APUs in a managed forest in the TNF in the eastern Brazilian Amazon. The hypothesis tested was that species-specific equations are more precise, and therefore are more appropriate for use in the Amazon region than generic ones.

\section{MATERIAL AND METHODS}

\section{Study area}

This study was conducted in the Tapajos National Forest (TNF), which is a federal Conservation Unit (CU) located in the western region of the State of Pará, along the Santarem-Cuiabá (BRI63) highway, and is part of the municipalities of Belterra, Aveiro, Placas and Ruropolis, with geographic coordinates $2^{\circ} 45$ to $4^{\circ} 10^{\prime} \mathrm{S}$ and $54^{\circ}$ $45^{\prime}$ to $55^{\circ} 30^{\prime} \mathrm{W}$ (Figure I). The CU occupies an area of approximately 544,927 ha, of which about 32,000 ha are reserved for a community forest management concession (Forest Management Area - FMA). The vegetation in the $\mathrm{CU}$ is classified as Ombrophilous Dense Forest and is characterized by the dominance of large individual trees, palms and epiphytes, with a uniform canopy or with emergent trees (Gonçalves and Santos, 2008).

\section{Data collection}

The data used in this study were from 29,119 trees $(50.0 \mathrm{~cm} \leq \mathrm{DBH} \leq 175.0 \mathrm{~cm})$ of 43 commercial species from 10 APUs (03 to 12) managed from 2008 to 2017 in the FMA of the TNF (Figure I). The area of the APUs varied between 52 I to I,723 ha, totaling approximately II,I36 


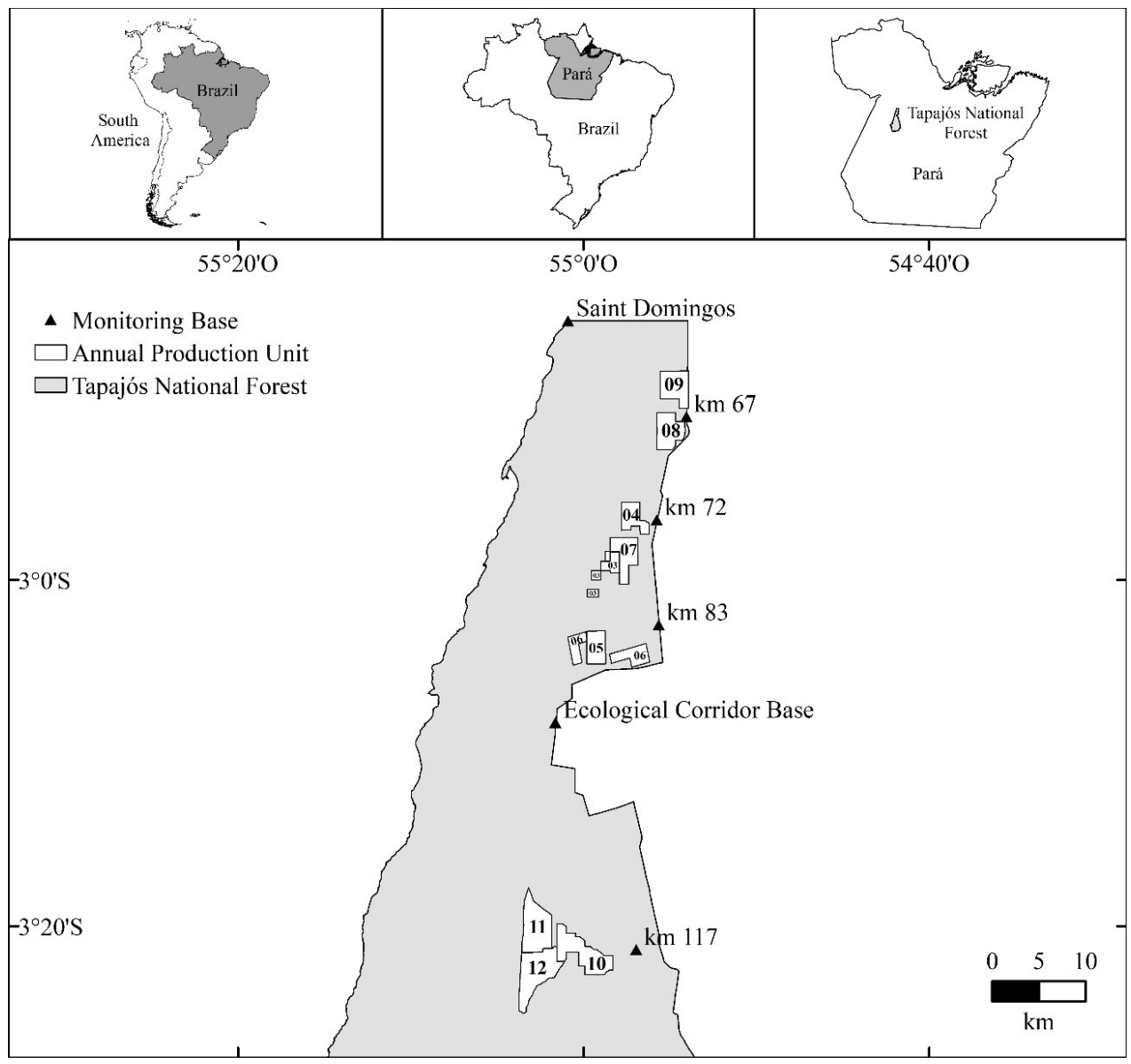

FIGURE I Map of the study area and Annual Production Units (APUs) where data was collected.

managed hectares. The data were collected through $100 \%$ forest inventories (census of all trees with $\mathrm{DBH} \geq 50 \mathrm{~cm}$ ) and rigorous volumetric measurements of logs.

In the 100\% forest inventories, besides species identification by common regional name, they were obtained diameter at $1.3 \mathrm{~m}$ above the soil surface $(\mathrm{DBH})$ and visually estimated commercial height $\left(h_{c}\right)$ for commercial trees. Volume was obtained through rigorous volumetric measurements using the Smalian method. Initially, volumes of individual logs were taken so that the sum of these, discounting the volume of hollows (when present) composed the commercial volume $\left(v_{c}\right)$ of the stem.

Besides $\mathrm{DBH}, \mathrm{h}_{\mathrm{c}}$ (visually estimated during the inventory) was used for modeling of $v_{c}$, although $h_{c}$ was also measured through the sum of the logs during the rigorous volumetric measurements. This procedure was justified by the fact that the sum of the logs was significant different than $h_{c}$ visually estimated during the inventory (Gomes et al., 2018). Since $h_{c}$ estimated in the inventory is the measurement used as input for the selected volumetric equation, this measurement was also chosen for the adjustment of the volumetric models.

\section{Data organization}

The dataset was separated into three categories to obtain three different types of equations, which differed in their scope: (I) for the FMA, independent of the APUs and species (generic equation for the FMA - GEFMA); (2) by APU, independent of the species (generic equations for the APUs - GEAPUs); and (3) by species (species-specific equations - SSEs). To obtain the GEFMA, all trees were used, which therefore involved all the APUs and all species. To obtain the GEAPUs and SSEs, the data were stratified by APU and by species, respectively.

About 10\% of the sample trees were previously selected to compose the validation dataset, and for this reason, these trees were not included in equation adjustment. This selection was done randomly, but proportional to the number of trees in each diameter class $(\mathrm{DBH})$. The selection was done for each species, and for validation of the generic equations the data were compiled into their respective categories (FMA and APUs).

The list of species and the number of trees in each dataset (adjustment and validation) are shown in Table I. 
The data distribution for the adjustment and validation, using the relationship between $\mathrm{v}_{c}$ and $\mathrm{DBH}$, are presented in Figure 2 for the 36 species with $n>30$, and in Figure 3 for the group "Others" (species with $n<30$ ).

\section{Selection and validation of the equations}

Among the volumetric models commonly used for tropical forests (Guendehou et al., 2012; Vibrans et al., 2015; Cysneiros et al., 2017; Gimenez et al., 2017; Tsega et al., 2018), four were tested for equation selection in the three categories (GEFMA, GEAPUs and SSEs). Two single input and two double input Model I (Kopezky \& Gehrhardt), Model 2 (Husch), Model 3 (Spurr),
Model 4 (Schumacher \& Hall) were used, where: $v_{c}=$ commercial volume, in $\mathrm{m}^{3}$; $\mathrm{DBH}=$ diameter at breast height (measured at $1.30 \mathrm{~m}$ above the soil), in $\mathrm{cm} ; \mathrm{h}_{\mathrm{c}}$ $=$ commercial height, in $\mathrm{m} ; b_{0}, b_{1}$ and $b_{2}=$ regression coefficients to be estimated; $\ln =$ neperiano logarithm; and $\varepsilon_{\mathrm{i}}=$ random error.

$$
\begin{aligned}
& \mathrm{v}_{\mathrm{c}}=\mathrm{b}_{0}+\mathrm{b}_{1} \mathrm{DBH}^{2}+\varepsilon_{\mathrm{i}} \\
& \operatorname{Inv}_{\mathrm{c}}=\mathrm{b}_{0}+\mathrm{b}_{1} \ln \mathrm{DBH}+\varepsilon_{\mathrm{i}} \\
& \operatorname{Inv}_{\mathrm{c}}=\mathrm{b}_{0}+\mathrm{b}_{1} \ln \left(\mathrm{DBH}^{2} \mathrm{~h}_{\mathrm{c}}\right)+\varepsilon_{\mathrm{i}} \\
& \operatorname{Inv}_{\mathrm{c}}=\mathrm{b}_{0}+\mathrm{b}_{1} \ln \mathrm{DBH}+\mathrm{b}_{2} \operatorname{Inh}_{\mathrm{c}}+\varepsilon_{\mathrm{i}}
\end{aligned}
$$

\begin{tabular}{|c|c|c|c|}
\hline Specie & Regional name & Adjustment & Validation \\
\hline Alexa grandiflora Ducke & Melancieira & 346 & 38 \\
\hline Apuleia leiocarpa (Vogel) J. F. Macbr. & Garapeira & 562 & 62 \\
\hline Astronium lecointei Ducke & Muiracatiara & 1,222 & 136 \\
\hline Bagassa guianensis Aubl. & Tatajuba & 490 & 54 \\
\hline Bowdichia sp. & Sucupira amarela & 114 & 12 \\
\hline Cedrela odorata $\mathrm{L}$. & Cedro vermelho & 99 & 11 \\
\hline Cedrelinga cateniformis (Ducke) Ducke & Cedrorana & 492 & 52 \\
\hline Cordia goeldiana Huber & Freijó cinza & 110 & 12 \\
\hline Couratari sp. & Tauarí & 2,974 & 330 \\
\hline Dipteryx odorata (Aubl.) Willd. & Cumarú & 274 & 30 \\
\hline Enterolobium schomburgkii (Benth.) Benth. & Fava rosca & 40 & 11 \\
\hline Goupia glabra Aulb. & Cupiúba & 390 & 42 \\
\hline Handroanthus impetiginosus (Mart. ex DC.) Mattos & Ipê roxo & 713 & 79 \\
\hline Handroanthus serratifolius (A.H.Gentry)S.Grose & Ipê amarelo & 396 & 44 \\
\hline Hymenaea courbaril L. & Jatobá & $\mathrm{I}, 487$ & 165 \\
\hline Hymenaea parvifolia Huber & Jutaí mirim & 605 & 66 \\
\hline Hymenolobium petraeum Ducke & Angelim pedra & 247 & 27 \\
\hline Lecythis lurida (Miers) S.A.Mori & Jarana & 2,836 & 315 \\
\hline Lecythis pisonis Cambess. & Sapucaia & 295 & 31 \\
\hline Manilkara bidentata (A. DC.) A. Chev. & Maparajuba & 170 & 19 \\
\hline Manilkara huberi (Ducke) A. Chev. & Maçaranduba & 6,582 & 728 \\
\hline Mezilaurus itauba (Meisn.) Taub. ex Mez. & Itaúba & 593 & 65 \\
\hline Ocotea baturitensis Vattimo & Louro preto & 325 & 35 \\
\hline Ocotea costulata (Nees) Mez. & Louro rosa & 191 & 20 \\
\hline Parkia multijuga Benth. & Fava tucupí & 331 & 35 \\
\hline Parkia sp. & Fava paricá & 30 & 8 \\
\hline Piptadenia suaveolens (Miq.) & Fava timborana & 503 & 56 \\
\hline Pouteria bilocularis (H.Winkl.) Baehni & Goiabão & 686 & 76 \\
\hline Pouteria oppositifolia (Ducke) Baehni & Guajará bolacha & 212 & 23 \\
\hline Pouteria sp. & Abiu de casca grossa & 161 & 17 \\
\hline Protium sp. & Breu amescla & 258 & 27 \\
\hline Swartzia laurifolia Benth. & Gombeira & 39 & 10 \\
\hline Terminalia sp. & Cuiarana & 273 & 30 \\
\hline Vatairea paraensis Ducke & Fava amargosa & 391 & 43 \\
\hline Virola melinonii (Benoist) A.C.Sm. & Virola & 161 & 17 \\
\hline Vochysia maxima Ducke & Quaruba & $\mathrm{I}, 54 \mathrm{I}$ & 172 \\
\hline- & Others & 62 & 20 \\
\hline Total & & 20,201 & 2,918 \\
\hline
\end{tabular}

TABLE I List of species and the number of trees in each dataset (adjustment and validation).

Others: grouped species because there was a low number of trees $(\mathrm{n}<30)$ (Dinizia excelsa Ducke - Angelim vermelho, Micropholis melinoniana Pierre - Currupixá, Enterolobium maximum Ducke - Fava timbaúba, Ocotea sp. - Louro vermelho, Buchenavia sp. - Mirindiba, Brosimum rubescens Taub. Muirapiranga and Astronium sp. - Mururé). 

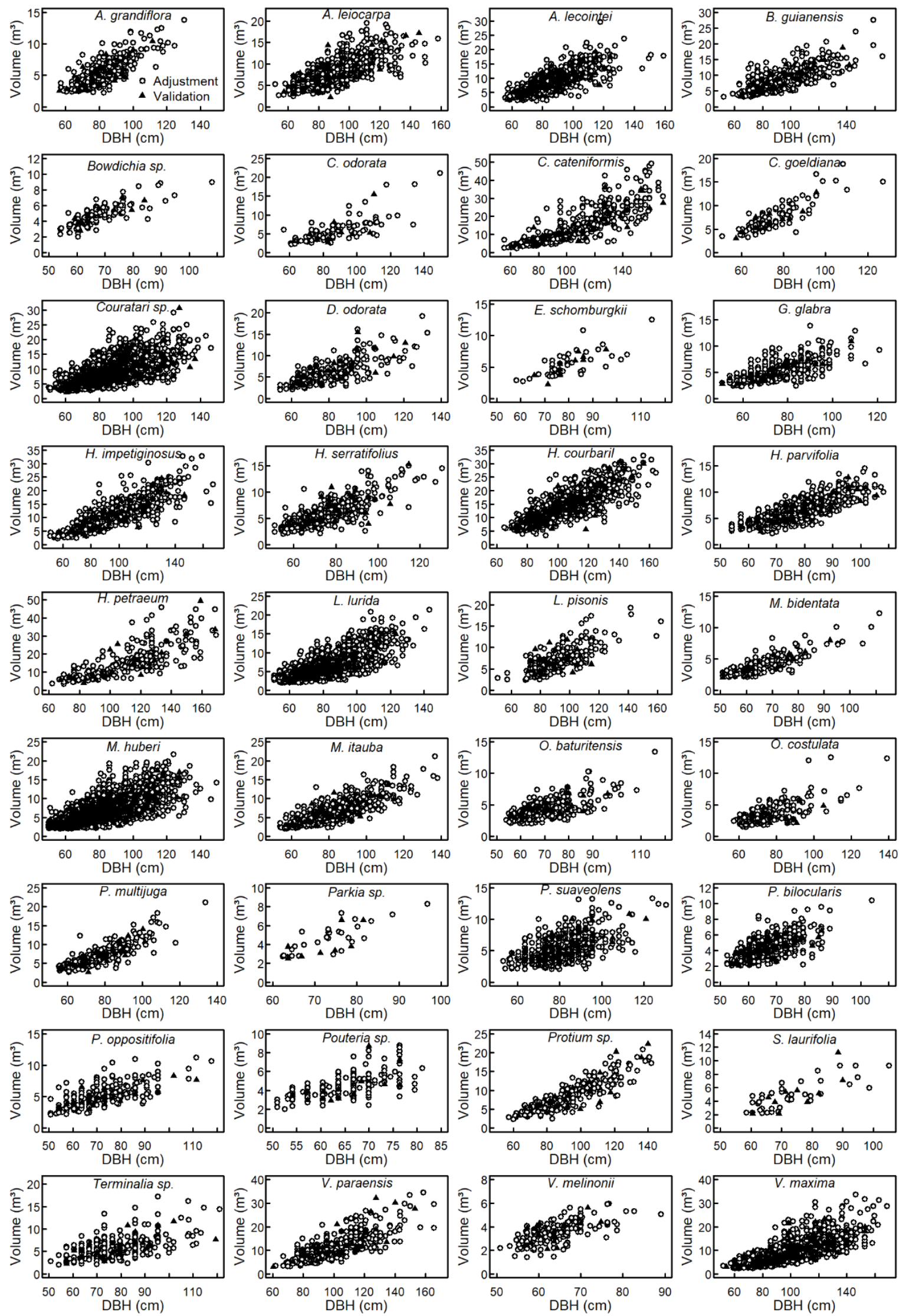

FIGURE 2 Data distribution for the adjustment and validation for the 36 species with $n>30$. 


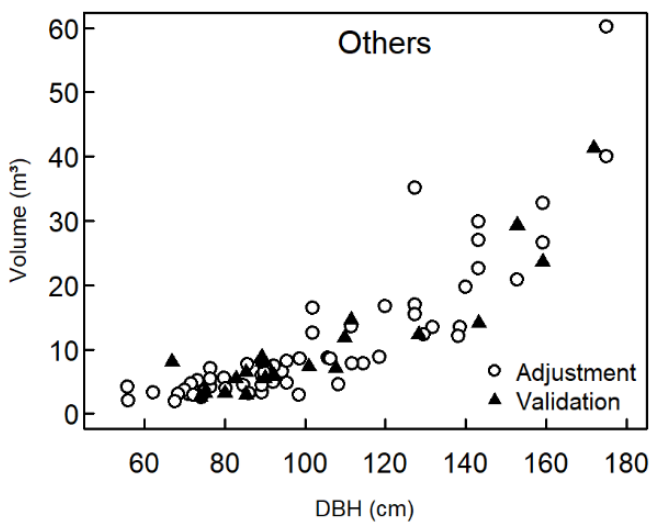

FIGURE 3 Data distribution for the adjustment and validation for the group "Others" (set of 7 species with $n<30$ ).

The coefficients of the volumetric models were estimated by the least squares method (LSM), using the ' $I m$ ' function of the software R version 3.6.0 (R Core Team, 2019). The significance of the coefficients was evaluated using a t-test $(\alpha=0.05)$ in the regression.

For evaluation of the adjustments and selection of the best equations, the adjusted coefficient of determination $\left(\mathrm{R}_{\mathrm{aj}}^{2}\right)$ was used, which expresses the quantity of the total variation that is explained by the regression (Campos and Leite, 2017); the standard error of the absolute estimate $\left(\mathrm{S}_{y x} \mathrm{~m}^{3}\right)$ and in percentage $\left(\mathrm{S}_{\mathrm{yx}} \%\right)$, which indicates the quality of the adjustment and how much the models errs on average when estimating the dependent variable (Machado et al., 2008) and the graphic dispersion of percent residuals $\left(\right.$ Res. $\%=\left(\left(v_{\text {observed }}\right.\right.$ $\left.\left.-v_{\text {estimated }}\right) / v_{\text {observed }}\right)(00)$ were used to reveal possible biases in the estimates (Campos and Leite, 20I7). The $\mathrm{R}_{\mathrm{aj}}{ }_{\mathrm{aj}}$ as well as the $S_{y x}$ were recalculated for arithmetic units in the case of logarithmic models.

The four models were tested separately for the FMA, for each of the APUs, and for each of the 36 species, as well as for the group "Others". After the evaluation of the adjustments, 48 equations were selected and compared.

Before comparing the selected equations in the three categories they were submitted to a process of statistical validation. In this process, after its use in the estimation of volumes in the validation dataset, a paired t-test $(\alpha=0.05)$ was used to compare estimated volumes with their respective observed values. When logarithmic equations were used the estimates were done using the original volume scale. The null hypothesis tested was that the estimated and observed volumes were statistically equal.

\section{Comparison of the selected equations}

To compare the selected equations in the three categories (GEFMA, GEAPUs and SSEs), they were applied to the validation dataset separately for each species. The precision of the estimates in relation to the observed volumes was measured using the following percentage statistics (Campos and Leite, 2017): Mean Squared Root Error (MSRE\%) (Equation 5), Bias (B\%) (Equation 6), and the Average Absolute Difference (AAD\%) (Equation 7). For which, when the values are nearer to zero the better the performance of the equation, where: $y_{i}=$ observed commercial volume of the $i^{\text {th }}$ tree, in $\mathrm{m}^{3} ; y_{i}=$ commercial volume estimated of the $i^{\text {th }}$ tree, in $\mathrm{m}^{3} ; \bar{y}=$ average observed commercial volume of the sample trees, in $\mathrm{m}^{3}$; $\mathrm{n}=$ number of observations.

$\operatorname{MSRE} \%=\frac{\sqrt{\sum_{\mathrm{i}=1}^{\mathrm{n}}(\mathrm{yi}-\hat{\mathrm{y} i})^{2} / \mathrm{n}}}{\overline{\mathrm{y}}} 100$

$\mathrm{B} \%=\frac{\sum_{\mathrm{i}=1}^{\mathrm{n}} \mathrm{yi}-\sum_{i=1}^{n} \hat{\mathrm{y}} \mathrm{i} / \mathrm{n}}{\overline{\mathrm{y}}} 100$

$\operatorname{AAD} \%=\frac{\sum_{\mathrm{i}=1}^{\mathrm{n}}|\mathrm{yi}-\hat{\mathrm{y}} \mathrm{i}| / \mathrm{n}}{\overline{\mathrm{y}}} 100$

Furthermore, direct comparisons for equations were done for (I) the entire validation dataset independent of APU and species; (2) the ten species of greatest commercial importance (largest volumes harvested) (A. lecointei, Couratari sp., $H$. impetiginosus, H. courbaril, H. parvifolia, L. lurida, M. huberi, M. itauba, $P$. bilocularis and V. maxima); and (3) for five species that commonly have high errors in estimates, especially due to large variability the data (C. odorata, $C$. cateniformis, $H$. petraeum, $P$. suaveolens and Terminalia sp.).

For the direct comparisons, the volumes estimated by the selected GEFMA, GEAPUs and SSEs were contrasted with the observed volumes. A trend line for the estimates was generated using the linear relationship between the observed and estimated volumes. Additionally, the residuals of the estimates were graphically analyzed and submitted to Analysis of Variance $(\alpha=0.05)$. Subsequently, the SNK test was applied (Student-Newman-Keuls) for comparison of means. All analyses were performed using $R$ software ( $R$ Core Team, 2019).

\section{RESULTS}

\section{Selection and validation of the equations}

Since a large number of equations was generated, and the principal objective of this study is to compare the best equations, only the equations selected in each of the three categories are shown in Table 2 . The complete 
list of tested equations, with their respective adjustment and precision statistics, are found in the supplementary information (Appendix A). Graphical distributions of the residuals of the selected equations are also presented in a supplementary document (Appendix B).

All the selected equations have just $\mathrm{DBH}$ as an independent variable (Table 2). The adjustment and precision statistics, as well as the graphical analysis of the percent residuals indicate similarity in the performance of these equations in relation to the equations that included $\mathrm{DBH}$ and $\mathrm{h}_{\mathrm{c}}$. This result is possibly a result of the fact that commercial height had non-sampling error in its measurement due to the difficulty in accurately measuring this variable, which compromises the precision of the volumetric estimates.

The generic equations (GEFMA and GEAPUs) had values of $\mathrm{R}^{2}$ aj varying between 0.64 and 0.76 , and $\mathrm{S}_{\mathrm{yx}}(\%)$ varying between 29.2 and $33.8 \%$. In general, there were improvements in the statistics for the SSEs, except for a few species. Among the species-specific equations, the equation for the group "Others" had the highest error, and this reflects the large variability of the data grouped for seven species. Without considering the equation from the "Others" group, the $\mathrm{R}_{\mathrm{aj}}^{2}$ varied from 0.30 to 0.79 between species, while the $S_{y x}(\%)$ varied between I8. I and $36.4 \%$ (Table 2). The estimated coefficients of all the selected equations were significant ( $p \leq 0.05$ ), according to the t-test from the regression.

All the selected equations were submitted to the validation test. The paired t-test $(\alpha \leq 0.05)$, showed that the equation selected for the FMA was not statistically valid ( $p=0.0019)$ for the estimates of species' commercial volumes. With respect to the generic equations by APU, only for APUs 03 and 04 were the observed and estimated volumes not statistically equal ( $p \leq 0.05)$. In contrast, all the species-specific equations were valid for the volumetric estimates ( $p \geq 0.05$ ), and therefore considered adequate for use. Despite this result in relation to the generic equations, the comparison of the selected equations in the three different categories of data was conducted.

\section{Comparison of the selected equations}

Table 3 shows the statistics for the analysis of estimate precision calculated by species, and consequently serves to compare the performance of selected equations in the three different categories.

The species-specific equations (SSEs) show much lower values of MSRE (\%), B (\%) and AAD (\%). This can also be seen in a more summarized manner by observing the weighted averages of the statistics at the end of Table 3. Furthermore, B (\%) had large variation in the tendency to under- and overestimate values between species. The values of $B(\%)$ varied between - I 01.9 and $26.4 \%$; -84.2 to $21.2 \%$ and -13.7 and $9.9 \%$ for GEFMA, GEAPUs and SSEs, respectively. From this perspective it can be concluded that, besides being statistically valid, the species-specific equations can generate more precise estimates when they are used for trees that were not part of the adjustment procedure, which is the principal objective of volumetric modeling.

In the direct comparison of the equations through contrast of the estimates in relation to the values observed for the entire validation dataset the trend lines were near the average (Figure 4 - Left). This occurred due to compensation by over- and underestimation since the number of trees was large. Although the three types of equations presented a trend to overestimate volumes (Figure 4 - Center), the ANOVA showed a significant difference between the residuals (Figure 4 - Right). Consequently, the means test revealed that the residuals generated by the SSEs were, on average, smaller and different than those generated by the other equations (GEFMA and GEAPUs).


FIGURE 4 (Left) Comparison of the volumetric equations using the values estimated by the Generic equation for the FMA (GEFMA), Generic equations for the APUs (GEAPUs) and Species-specific equations (SSEs) in relation to the values observed for the entire validation dataset. (Center) Comparison of the three types of equations using the residual distribution. (Right) Comparison of the three types of equations using the residual means test. 
TABLE 2 Volumetric equations selected for the three categories of data and their respective adjustment and precision statistics.

\begin{tabular}{|c|c|c|c|c|c|c|}
\hline Category & Dataset & Model & Equation & $\mathrm{R}^{2}$ & $\mathrm{~S}_{\mathrm{u}}\left(\mathrm{m}^{3}\right)$ & $\mathrm{S}_{y(}(\%)$ \\
\hline GEFMA & FMA & 1 & $v_{c}=-0.19455+0.00104 D_{B H}^{2}$ & 0.67 & 2.535 & 33.7 \\
\hline \multirow[t]{10}{*}{ GEAPUs } & APU 03 & I & $v_{c}=0.44099+0.00086 \mathrm{DBH}^{2}$ & 0.64 & 2.529 & 33.1 \\
\hline & APU 04 & I & $v_{c}=0.06325+0.00090 \mathrm{DBH}^{2}$ & 0.66 & 2.204 & 30.9 \\
\hline & APU 05 & I & $v_{c}^{c}=-0.08363+0.00098 \mathrm{DBH}^{2}$ & 0.68 & 2.332 & 31.0 \\
\hline & APU 06 & I & $v_{c}^{c}=0.14235+0.00100 D B B H^{2}$ & 0.71 & 2.197 & 29.2 \\
\hline & APU 07 & 2 & $v_{c}=\exp (-8.06324+2.24445 \ln (D B H))$ & 0.69 & 2.231 & 31.1 \\
\hline & APU 08 & I & $v_{c}=-0.21384+0.00095 \mathrm{DBH}^{2}$ & 0.65 & 2.408 & 32.1 \\
\hline & APU 09 & I & $v_{c}^{c}=-0.91130+0.00104 D B B H^{2}$ & 0.69 & 2.385 & 31.8 \\
\hline & APU 10 & I & $v_{c}^{c}=-0.68307+0.00118 \mathrm{DBH}^{2}$ & 0.70 & 2.748 & 33.8 \\
\hline & APU II & 2 & $v_{c}=\exp (-7.2020 I+2.08964 \ln (D B H))$ & 0.76 & 2.406 & 32.3 \\
\hline & APU 12 & 1 & $v_{c}=0.00205+0.00114 \mathrm{DBH}^{2}$ & 0.64 & 2.343 & 32.8 \\
\hline \multirow[t]{37}{*}{ SSES } & A. grandiflora & 1 & $v_{c}=0.17249+0.00076 \mathrm{BDH}^{2}$ & 0.63 & 1.269 & 23.8 \\
\hline & A. leiocarpa & 2 & $\mathrm{v}_{c}=\exp (-4.62610+1.47319 \ln (\mathrm{DBH}))$ & 0.47 & 2.376 & 29.8 \\
\hline & A. lecointei & 2 & $v_{c}^{c}=\exp (-6.92187+2.02237 \ln (D B H))$ & 0.63 & 2.164 & 26.7 \\
\hline & B. guianensis & 2 & $v_{c}^{c}=\exp (-4.75809+1.51039 \ln (D B H))$ & 0.54 & 2.301 & 27.0 \\
\hline & Bowdichia sp. & l & ${ }^{c} v_{c}=1.04606+0.00078 \mathrm{DBH}^{2}$ & 0.60 & 0.861 & 18.1 \\
\hline & C. odorata & I & $v_{c}^{c}=0.2336 \mathrm{I}+0.00072 \mathrm{DBH}^{2}$ & 0.60 & 2.031 & 34.1 \\
\hline & C. cateniformis & 2 & $v_{c}={ }_{c}^{c} \exp (-7.96567+2.24882 \ln (D B H))$ & 0.69 & 5.081 & 36.4 \\
\hline & C. goeldiana & 2 & $v_{c}^{c}=\exp (-6.64676+1.98957 \ln (\mathrm{DBH}))$ & 0.71 & 1.553 & 21.4 \\
\hline & Couratari sp. & 2 & $v_{c}^{c}=\exp (-5.53516+1.7 \mid 104 \ln (D B H))$ & 0.48 & 2.635 & 31.0 \\
\hline & D. odorata & 2 & $\mathrm{v}_{c}{ }_{c}=\exp (-5.85579+1.73314 \ln (\mathrm{DBH}))$ & 0.56 & 1.803 & 29.6 \\
\hline & E. schomburgkii & 2 & $v_{c}=\exp (-6.11244+1.77587 \ln (D B H))$ & 0.49 & 1.465 & 26.3 \\
\hline & G. glaba & 2 & $v_{c}^{c}=\exp (-4.762 I I+I .47646 \ln (D B H))$ & 0.42 & 1.443 & 27.4 \\
\hline & H. impetiginosus & 2 & $v_{c}^{c}=\exp (-6.47523+1.92940 \ln (\mathrm{DBH}))$ & 0.69 & 2.941 & 26.3 \\
\hline & H. serratifolius & 2 & $v_{c}^{c}=\exp (-5.84846+1.74585 \ln (D B H))$ & 0.62 & 1.537 & 26.4 \\
\hline & H. courbaril & 2 & $v_{c}^{c}=\exp (-6.24458+1.90015 \ln (D B H))$ & 0.69 & 2.860 & 21.2 \\
\hline & H. parvifolia & I & $v_{c}=0.12774+0.00103 \mathrm{DBH}^{2}$ & 0.61 & 1.355 & 21.0 \\
\hline & H. petraeum & 2 & $v_{c}=\exp (-7.22502+2.09783 \ln (D B H))$ & 0.61 & 5.567 & 36.4 \\
\hline & L. lurida & 2 & $v_{c}^{c}=\exp (-6.78776+1.95013 \ln (\mathrm{DBH}))$ & 0.62 & 1.686 & 27.5 \\
\hline & L. pisonis & 2 & $v_{c}^{c}=\exp (-6.33215+1.81898 \ln (D B H))$ & 0.56 & 1.857 & 27.2 \\
\hline & M. bidentata & 2 & $v_{c}^{c}=\exp (-6.60036+1.89356 \ln (\mathrm{DBH}))$ & 0.68 & 0.950 & 22.6 \\
\hline & M. huberi & 2 & $v_{c}^{c}=\exp (-5.9534 I+1.76982 \ln (D B H))$ & 0.60 & 1.759 & 28.4 \\
\hline & M. itauba & 2 & $v_{c}^{c}=\exp (-7.25817+2.05543 \ln (\mathrm{DBH}))$ & 0.68 & 1.712 & 26.2 \\
\hline & O. baturitensis & 2 & $v_{c}^{c}=\exp (-5.14616+1.54597 \ln (D B H))$ & 0.46 & 1.122 & 25.8 \\
\hline & O. costulata & 2 & $v_{c}^{c}=\exp (-6.5|835+1.78| 44 \ln (\mathrm{DBH}))$ & 0.49 & 1.227 & 34.1 \\
\hline & P. multijuga & I & $v_{c}=0.01311+0.00115 \mathrm{DBH}^{2}$ & 0.74 & 1.436 & 20.7 \\
\hline & Parkia sp. & 2 & $v_{c}=\exp (-9.25946+2.50440 \ln (D B H))$ & 0.62 & 0.951 & 20.4 \\
\hline & P. suaveolens & I & $v_{c}=1.38704+0.00060 \mathrm{DBH}^{2}$ & 0.33 & 1.772 & 32.5 \\
\hline & P. bilocularis & 2 & $v_{c}=\exp (-5.758 I 5+1.71627 \ln (D B H))$ & 0.39 & 0.940 & 22.0 \\
\hline & P. oppositifolia & 2 & $v_{c}^{c}=\exp (-4.91776+1.52652 \ln (D B H))$ & 0.48 & 1.307 & 25.0 \\
\hline & Pouteria sp. & 2 & $v_{c}^{c}=\exp (-5.78060+1.73806 \ln (D B H))$ & $0.4 I$ & 0.999 & 22.1 \\
\hline & Protium sp. & 2 & $v_{c}^{c}=\exp (-6.96344+1.99652 \ln (D B H))$ & 0.79 & 1.739 & 20.2 \\
\hline & S. laurifolia & 2 & $v_{c}^{c}=\exp (-7.44|3|+2.08624 \ln (D B H))$ & 0.58 & 1.314 & 27.0 \\
\hline & Terminalia sp. & 2 & $v_{c}^{c}=\exp (-4.40532+1.402 I I \ln (\mathrm{DBH}))$ & 0.30 & 2.081 & 35.8 \\
\hline & V. paraensis & 2 & $v_{c}^{c}=\exp (-6.93716+2.01769 \ln (D B H))$ & 0.60 & 3.451 & 29.7 \\
\hline & V. melinonii & 2 & $v_{c}=\exp (-6.22312+1.78847 \ln (D B H))$ & 0.39 & 0.707 & 20.3 \\
\hline & V. maxima & 2 & $v_{c}^{c}=\exp (-6.66554+1.90852 \ln (\mathrm{DBH}))$ & 0.55 & 3.027 & 34.0 \\
\hline & Others & 2 & $v_{c}^{c}=\exp (-9.57704+2.5356 / \ln (\mathrm{DBH}))$ & 0.76 & 5.295 & 48.0 \\
\hline
\end{tabular}

GEFMA = Generic Equation for the Forest Management Area; GEAPUs = Generic Equations for the Annual Production Units; SSEs = Species-specific equations; FMA $=$ Forest Management Area; APU = Annual Production Units; $\mathrm{R}_{\mathrm{aj}}^{2}=$ adjusted coefficients of determination; $\mathrm{S}_{\mathrm{yx}}\left(\mathrm{m}^{3}\right)=$ errors of the absolute estimates; $\mathrm{S}_{\mathrm{yx}}(\%)=$ errors of the percentage estimates; $b_{0}$ and $b_{1}=$ estimated coefficients; $v_{c}=$ commercial volume; DBH = diameter at breast height (measured at $1.30 \mathrm{~m}$ above the soil); Others: grouped species (D. excelsa, M. melinoniana, E. maximum, Ocotea sp., Buchenavia sp., B. rubescens and Astronium sp.).

In the comparison of the equations for the ten most important commercial species, the contrast of the estimated and observed values showed that the SSEs generated more precise estimates, with trend lines nearer to the mean for most species (Figure 5 - Left). The analysis of the distribution of the residuals revealed gains in estimate precision by the SSEs for most species (Figure 5 - Center), although these were slight.
The superiority of the SSEs becomes evident when comparing the residual means. The ANOVA showed a significant difference $(p<0.05)$ for all ten species except $H$. impetiginosus and $H$. parvifolia (Figure 5 - Right). The means comparison test showed that the residuals generated from the estimates made by the SSE were, on average, different and nearer to zero than the residuals generated by the GEFMA and GEAPUs. 
TABLE 3 Statistics for the precision of estimates generated for each species using selected generic and species-specific equations for managed commercial species in the Forest Management Area of the Tapajos National Forest, eastern Amazonia, Brazil.

\begin{tabular}{|c|c|c|c|c|c|c|c|c|c|}
\hline \multirow{2}{*}{ Species } & \multicolumn{3}{|c|}{ GEFMA } & \multicolumn{3}{|c|}{ GEAPUs } & \multicolumn{3}{|c|}{ SSEs } \\
\hline & MSRE (\%) & B (\%) & AAD (\%) & MSRE (\%) & B (\%) & AAD (\%) & MSRE (\%) & $\mathrm{B}(\%)$ & AAD (\%) \\
\hline A. grandiflora & 39.15 & -29.78 & 32.47 & 30.42 & $-|7.0|$ & 23.76 & 23.63 & -0.85 & 19.36 \\
\hline A. leiocarpa & 31.68 & -8.51 & 25.56 & 33.92 & -13.83 & 26.75 & 28.46 & 5.24 & 22.43 \\
\hline A. lecointei & 27.26 & 11.26 & 20.10 & 26.84 & 13.58 & 20.02 & 24.95 & 1.62 & 18.42 \\
\hline B. guianensis & 25.79 & -8.41 & 18.55 & 24.20 & -8.70 & 16.30 & 22.41 & 2.96 & 18.48 \\
\hline Bowdichia sp. & $|4.3|$ & 2.88 & 11.66 & 14.62 & 8.02 & 12.22 & 13.79 & 2.04 & 10.25 \\
\hline C. odorata & 60.84 & -39.37 & 50.93 & 51.59 & -37.07 & 43.96 & 47.31 & -2.81 & 35.56 \\
\hline C. cateniformis & 34.91 & 9.44 & 22.14 & 33.22 & 10.70 & 22.34 & 32.75 & -0.35 & 21.50 \\
\hline C. goeldiana & 46.29 & 26.49 & 26.97 & 43.16 & 21.25 & 22.97 & 39.41 & 9.20 & 23.05 \\
\hline Couratari sp. & 33.47 & 10.44 & 23.42 & 33.64 & 10.15 & 23.49 & 31.39 & 0.77 & 22.69 \\
\hline D. odorata & 33.07 & -4.26 & 25.40 & 33.38 & -7.42 & 26.08 & 33.04 & 9.91 & 24.80 \\
\hline E. schomburgkii & 28.66 & -23.64 & 24.69 & 18.92 & -9.75 & 14.94 & 18.95 & -1.40 & 14.72 \\
\hline G. glaba & 21.46 & -12.68 & 16.15 & 30.63 & -23.55 & 24.28 & 15.72 & 1.79 & 12.89 \\
\hline H. impetiginosus & 27.26 & 7.52 & 21.28 & 25.32 & 4.51 & 20.23 & 26.37 & -0.59 & 20.03 \\
\hline H. serratifolius & 29.16 & 2.90 & 21.51 & 26.63 & 0.94 & 18.11 & 29.11 & 6.73 & 21.40 \\
\hline H. courbaril & 28.32 & 19.45 & 22.51 & 29.23 & 21.19 & 23.79 & 20.10 & 1.94 & 14.10 \\
\hline H. parvifolia & 18.28 & 2.91 & 14.53 & 20.26 & 7.64 & 15.63 & 18.07 & -0.73 & $\mid 4.8 \mathrm{I}$ \\
\hline H. petraeum & 42.50 & 15.69 & 25.66 & 40.35 & 16.64 & 23.44 & 37.04 & 4.38 & 23.57 \\
\hline L. lurida & 32.38 & -15.25 & 24.72 & 26.15 & -8.07 & 19.34 & 27.24 & -3.10 & 20.60 \\
\hline L. pisonis & 42.27 & -18.96 & 34.93 & 38.53 & -21.59 & 31.51 & 37.27 & 8.15 & 26.71 \\
\hline M. bidentata & 18.78 & $-|1.8|$ & 14.59 & 27.05 & -22.03 & 22.48 & 15.11 & 2.97 & 12.33 \\
\hline M. huberi & 31.05 & $-|0.6|$ & 23.35 & 26.07 & -9.31 & 19.04 & 26.62 & -2.97 & 20.18 \\
\hline M. itauba & 41.05 & -18.49 & 28.79 & 38.96 & -13.35 & 28.78 & 34.86 & -5.62 & 24.35 \\
\hline O. baturitensis & 26.34 & -11.69 & 18.78 & 22.27 & -0.40 & 16.82 & 20.29 & 6.31 & 15.13 \\
\hline O. costulata & 115.37 & -101.98 & 101.98 & 98.37 & -84.23 & 84.23 & 34.36 & -13.75 & 25.65 \\
\hline P. multijuga & 21.89 & 11.00 & 16.36 & 26.32 & 16.94 & 20.58 & 18.29 & -1.99 & 13.62 \\
\hline Parkia sp. & 40.45 & -30.14 & 34.56 & 32.72 & -18.22 & 29.39 & 27.92 & -7.66 & 26.27 \\
\hline P. suaveolens & 36.75 & $-|7.5|$ & 28.95 & 37.06 & -19.59 & 29.69 & 30.15 & 7.30 & 21.25 \\
\hline P. bilocularis & 20.06 & -4.94 & 16.43 & 21.63 & -9.80 & 16.95 & $18.5 \mid$ & -0.96 & 14.75 \\
\hline P. oppositifolia & 36.11 & -17.28 & 25.76 & 47.08 & -30.13 & 34.38 & 22.36 & -8.87 & 16.92 \\
\hline Pouteria sp. & 26.63 & 4.43 & 19.02 & 27.82 & -9.63 & 21.42 & 32.89 & 1.07 & 23.15 \\
\hline Protium sp. & 26.85 & -6.03 & $18.9 \mid$ & 25.53 & -0.07 & 18.67 & 26.98 & 3.10 & 20.24 \\
\hline S. laurifolia & 34.35 & -12.77 & 27.50 & 30.42 & -6.17 & 23.79 & 33.70 & 4.37 & 24.12 \\
\hline Terminalia sp. & 35.37 & -9.18 & 26.82 & 38.48 & -12.59 & 26.34 & 31.02 & 4.21 & 23.74 \\
\hline V. paraensis & 35.94 & 11.03 & 24.45 & 32.57 & 5.23 & 21.53 & 34.96 & 8.13 & 24.18 \\
\hline V. melinonii & 26.75 & -13.82 & 23.18 & 17.39 & -1.77 & 14.99 & 22.91 & 5.47 & 18.83 \\
\hline V. maxima & 37.81 & -18.03 & 30.47 & 34.65 & -13.77 & 26.14 & 31.52 & 3.71 & 21.32 \\
\hline Others & 36.80 & -9.69 & 29.66 & 30.52 & -12.43 & 25.23 & 31.41 & 3.33 & 24.50 \\
\hline Averages & 31.93 & -5.22 & 24.12 & 29.58 & -3.72 & 22.01 & 27.16 & 0.06 & 20.08 \\
\hline
\end{tabular}

GEFMA = Generic Equation for the Forest Management Area; GEAPUs = Generic Equations for the Annual Production Units; SSEs = Species-specific equations; MSRE = Mean Squared Root Error; $B=$ Bias; AAD = Average Absolute Difference; Others: grouped species because there was a low number of trees $(n<30)(D$. excelsa, M. melinoniana, E. maximum, Ocotea sp., Buchenavia sp., B. rubescens and Astronium sp.).

Consequently, the trends of over- and underestimation were reduced when the SSEs were used.

The species $M$. huberi had the largest volume harvested in the ten UPAs (approximately $24 \%$ of the total volume), and had its total volume overestimated by the validation dataset by 10.6, 9.3 and $3.0 \%$ when the GEFMA, the GEAPUs and the SSE were used, respectively. Couratari sp., in contrast, with the second largest volume harvested, had its volume underestimated by 10.4 and $10.1 \%$ when the GEFMA and the GEAPUs were used, respectively; however, when the SSE was used for this species the volume was underestimated by just $0.8 \%$.
As shown in Table 2, even the best equations developed for $C$. odorata, $C$. cateniformis, $H$. petraeum, $P$. suaveolens and Terminalia sp. had high estimate errors $\left(\mathrm{S}_{y x}>30 \%\right)$. This is a function of the large variability in the data for this species, especially for large trees, which complicates model adjustment. In the comparison of the equations for these five species there are relevant gains in precision when the SSEs are used.

When contrasting the generated estimates with the observed values, the trend lines for the estimates made by the SSEs were nearer to the mean (Figure 6 - Left). The distribution of the residuals showed a reduction in tendencies to under- and overestimate volumes using the 

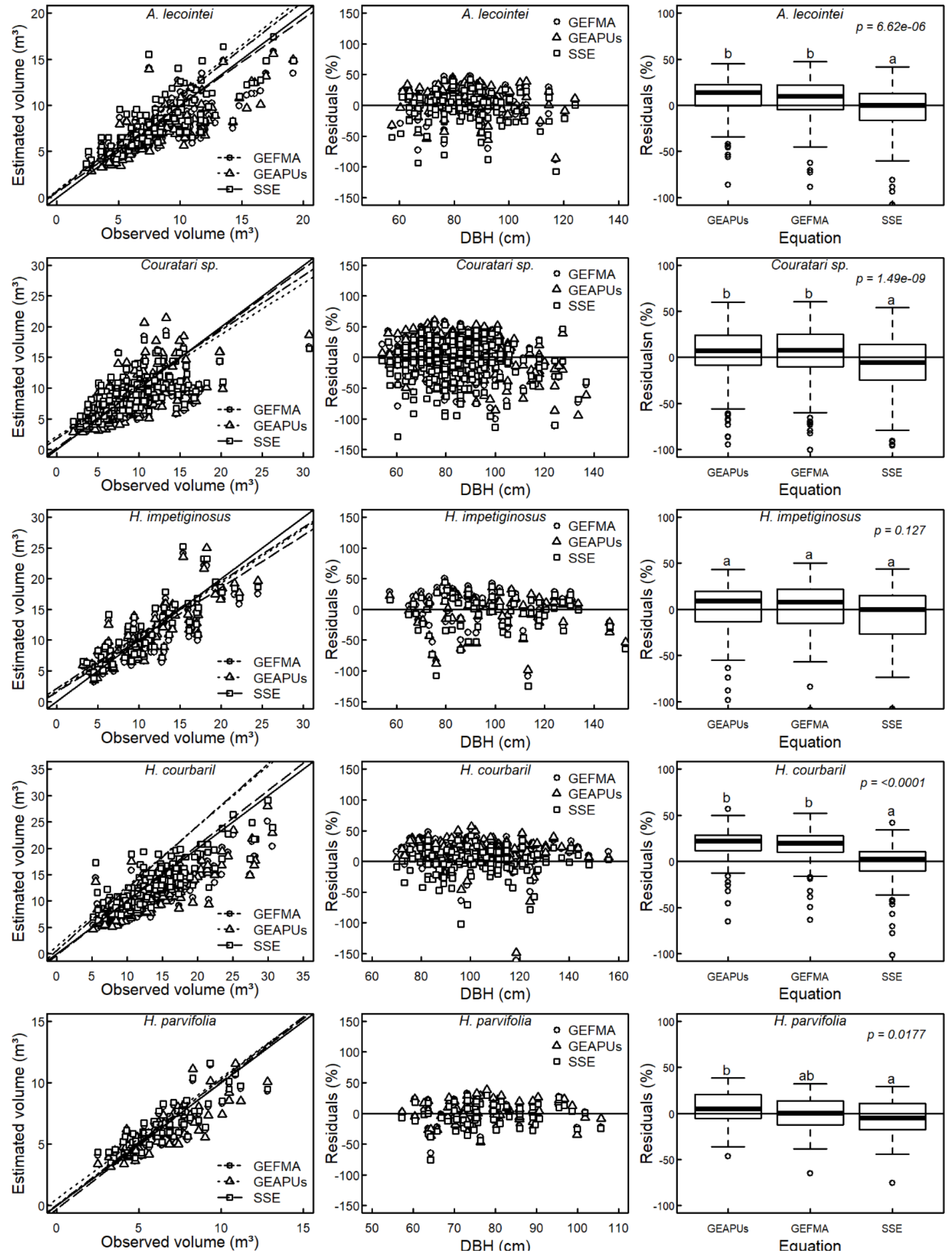

FIGURE 5 (Left) Comparison of the volumetric equations using the values estimated by the Generic equation for the FMA (GEFMA), Generic equations for the APUs (GEAPUs) and Species-specific equation (SSE) in relation to the values observed for the ten most important commercial species. (Center) Comparison of the three types of equations using the residual distribution. (Right) Comparison of the three types of equations using the residual means test. 

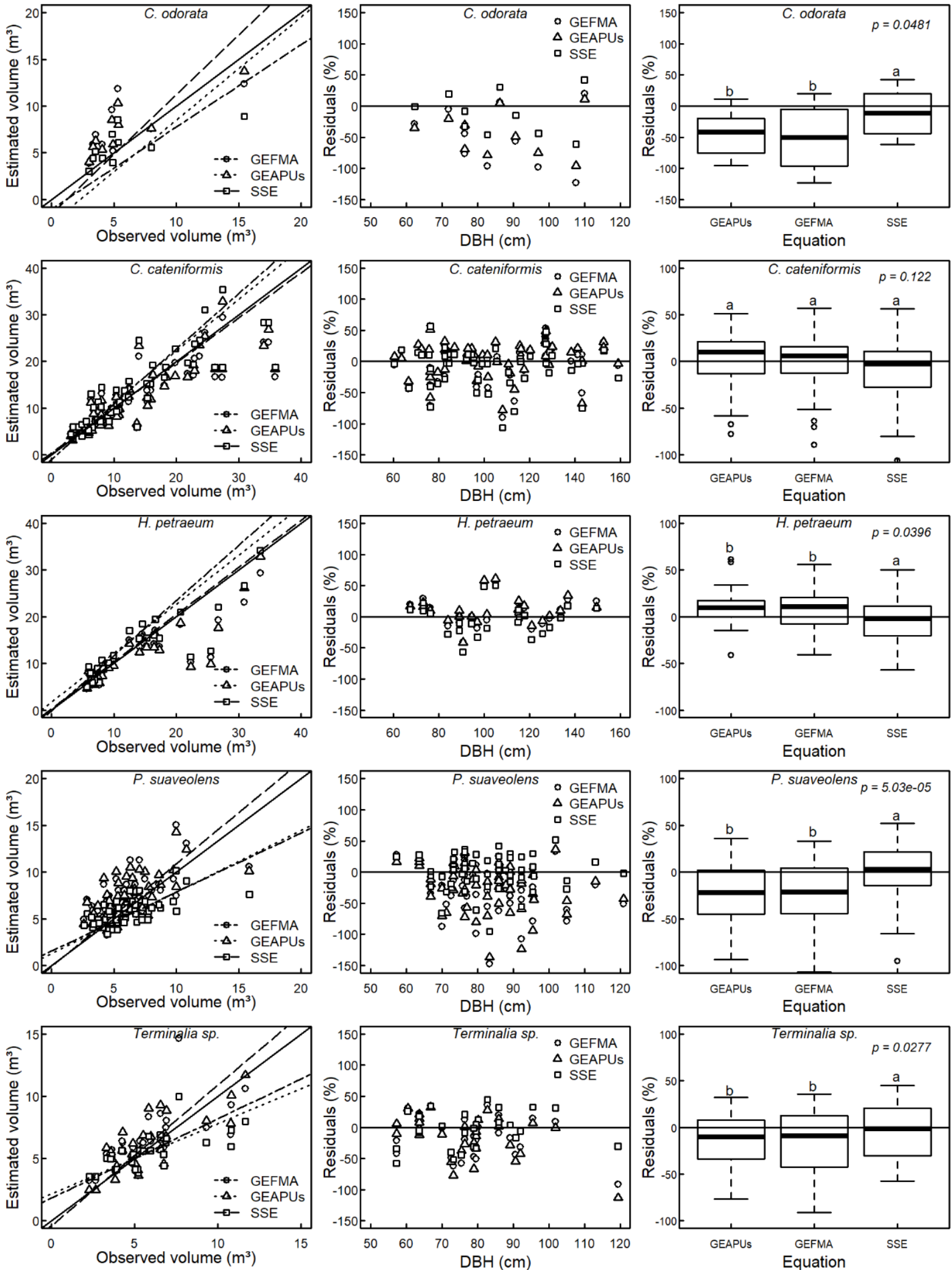

FIGURE 6 (Left) Comparison of the volumetric equations using the values estimated by the Generic equation for the FMA (GEFMA), Generic equations for the APUs (GEAPUs) and Species-specific equation (SSE) in relation to the values observed for the five species with the highest estimation error. (Center) Comparison of the three types of equations using the residual distribution. (Right) Comparison of the three types of equations using the residual means test. 
SSEs (Figure 6 - Center). The ANOVA indicated a significant difference between the residuals generated by the three types of equations, except for the species $C$. cateniformis (Figure 6 - Right). The means comparison test showed that the SSEs were different than the generic equations (GEFMA and GEAPUs), with relevant gains in precision (Figure 6 Right). Despite the non-significant ANOVA for the residuals of $C$. cateniformis, there was greater precision of the SSE, for the comparison of estimated volumes as well as for the evaluation of the residuals.

$H$. petraeum, one of the commercial species with the largest trees (Mean DBH $=109 \mathrm{~cm}$ ), commonly has its volume underestimated. However, when the SSE is used for this species the underestimation was just $4.4 \%$, while for the GEFMA and the GEAPUs the underestimation was 15.7 and $16.6 \%$, respectively. In a similar manner $C$. cateniformis (Mean $\mathrm{DBH}=105 \mathrm{~cm}$ ) had its volume underestimated by 9.4 and $10.7 \%$ by the GEFMA and GEAPUs, respectively, while the SSE overestimated the volume of this species by $0.3 \%$.

\section{DISCUSSION}

For the selection of the three types of equations (GEFMA, GEAPUs and SSEs), the single-input equations were chosen since these had similar performance to the double-input equations. Although not very common, single input generic equations have been tested and recommended for commercially managed species in diverse regions of the Amazon (Barros and Silva Júnior, 2009; Thaines et al., 2010; Barreto et al., 2014; Tonini and Borges, 2015; Gimenez et al., 2015; Gimenez et al., 2017). Results from these studies have shown that the use of single input generic equations reduced inventory time and cost, and one of the principal advantages is that intrinsic non-sampling error of the visual estimates of $h_{c}$ is eliminated.

In tropical forest ecosystems it is often difficult to measure commercial tree height with precision due to the presence of various strata and a closed canopy. Models that use only $\mathrm{DBH}$ as an explanatory variable are therefore useful in this case and have shown good results (Segura and Kanninen, 2005; Goussanou et al., 2016; Gimenez et al., 2017; Kora et al., 2018). When it is possible to rigorously measure commercial tree height in forest inventories, the use of double input equations should be prioritized.

It should be emphasized that the large errors in the estimates, principally for the selected generic equations, is due, in large part, to heterogeneity in dendrometric variables of the species. These results were also reported by other studies conducted in the
Amazon (Hiramatsu, 2008; Cysneiros, 2016). As in the studies by these authors, normally high $\mathrm{S}_{\mathrm{yx}}$ and low $\mathrm{R}_{\mathrm{aj}}$ are linked to the use of a large number of sample trees.

The SSEs for certain species such as $C$. odorata, C. cateniformis, Couratari sp., $H$. petraeum, O. costulata, P. suaveolens, Terminalia sp., V. maxima, and the "Others" group also had high errors ( $\left.\mathrm{S}_{\mathrm{yx}}>30 \%\right)$, similar to those for the generic equations. This is probably due to the fact that these species have large structural variability, a common characteristic for large trees and where the largest errors in volumetric modeling occurs for tropical species (Brandeis et al., 2006).

The validation of the best equations indicated that, although the generic equations had satisfactory performance with respect to the adjustment and precision statistics and residual evaluation, would be inadequate for use in a new dataset because they can produce biased estimates. The species-specific equations, however, have the advantage of being validated by the t-test, indicating that their estimated volumes were statistically equal to the observed volumes.

Comparing the generic and species-specific equations through precision statistics revealed relevant variation in the generic equations in the tendencies for under- and overestimation between species, indicated by the values of $B(\%)$. This is a characteristic of generic equations when they are used to estimate the volume of individual species (Akindele and Lemay, 2006). This could be problematic for forest management planning since each species has specific restrictions, such as authorized harvest volume for each species. Furthermore, when species estimates are imprecise, the prediction for total production of a forest is incorrect.

The direct comparisons through contrasts of estimated and observed volumes for the entire dataset indicated that the errors in under- and overestimation tended to compensate each other due to the large quantity of data. This suggests that the generic equations are as efficient as the specific ones at making volume estimates for a set of data without stratification by APU or by species. However, as previously stated, there is a necessity to generate species-based estimates for forest management in the Amazon, which increases the importance of using of species-specific equations. Furthermore, the evaluation of the residuals through ANOVA and the means comparison indicated lower error using from the SSEs.

In this study, the precision statistics also demonstrated a gradual reduction in the estimated errors due to the stratification of data by APU and, principally, 
by species. The greater precision of the SSEs compared to the GEFMA and the GEAPUs, indicates that the results of individual evaluation using precision statistics are confirmed by direct comparison of equations. Species of greater commercial importance and those with large errors in their volume estimates were measured with greater precision by the SSEs, which could possibly occur for the remainder of the species in this study.

Species that have a high market demand, and that consequently have greater harvest volumes, need precise equations since systematic errors in estimates for these species represents under- or overestimation of a large quantity of cubic meters of commercial volume. Furthermore, for species that commonly have very largesized individuals (average DBH $>100 \mathrm{~cm}$ ), volumetric modeling is particularly challenging (Brandeis et al., 2006; Cysneiros, 2016) and generic equations normally tend to under- or overestimate volumes. However, the results of the current study also show important gains in precision can be achieved for these species by using SSEs. In forest management areas, this is particularly important because exceptionally large trees obviously represent a large portion of total commercial volume.

The results confirm the importance of a reduction in variation of data to obtain more efficient equations, as emphasized by Finger (2006). The principal advantage of stratification of data by species was an increase in the correlation between $v_{c}$ and $\mathrm{DBH}$, which undoubtedly contributed to a better adjustment of the models to the data. In certain cases, dataset stratification by species may be inviable from the point of view of sample representativity. However, this was not a problem in this study since after stratification most species remained well-represented with sample trees from across the range of species diameter.

Despite the greater facility in obtaining and using generic equations, they should be used in commercial tropical forests with caution. In the Amazon, besides their use being predominant, during many years an equation dependent on a form factor of 0.7 , recommended by Heinsdijk and Bastos (1963), and generic equations adjusted using data from the TNF have been used in a generalized manner in a diversity of sites.

During recent years, equations have been adjusted for specific management areas in the Amazon (Rolim et al., 2006; Barros and Silva Júnior, 2009; Thaines et al., 20I0; Barreto et al., 20I4; Silva and Santana, 20I4; Gimenez et al., 20I5). However, these are equations used, generally, in a generalized manner for all species present in all production units that are managed annually. Furthermore, in the majority of cases, these are equations that were developed using a small number of trees, measured in specific places in management areas, thus reducing their representativity.

In the FMA in the TNF, Gomes et al. (2018) reported that an equation that was adjusted specifically for an APU was more precise than a general equation for the TNF and an equation related to the average form factor. Similar results were found by other studies when equations were developed for smaller areas (Mauya et al. 20I4, Vibrans et al. 20I5; Kachamba and Eid, 20I6). These results indicate that there is a gain in precision when data stratification in relation to area is done, possibly due to a reduction in edaphoclimatic variation. Even though there is a gain in precision, the heterogeneity between species can still be a limiting factor for generation of adequate equations, and therefore should be taken into consideration.

Kora et al. (2018) compared species-specific volume equations with a generic equation in Benin in west Africa and found greater precision for the specific equations. The authors related that the generic equation had difficulty in estimating volume with precision, even though it was developed using data from the same forest ecosystem (the same edaphoclimatic conditions). Similar results were reported by Guendehou et al. (20I2) and Goussanou et al. (2016) in the same region.

In the Brazilian Amazon, Cysneiros et al. (2017) tested generic equations for 32 commercial species, and species-specific equations for 12 principal species. Although direct comparisons of the estimates made by the selected equations were not done, the authors found better performance of species-specific equations through adjustment and precision statistics.

In the state of Amazonas, Krainovic et al. (2017) compared an equation specific for Aniba rosaeodora Ducke with a general equation based on the average form factor, which is commonly used in the Brazilian Amazon. These authors found that the general equation overestimated observed volumes by $32.8 \%$, while the specific equation overestimated volume by just $0.15 \%$. The use of a general equation with a single form factor for all situations could explain the elevated error generated by this equation.

Various factors can explain the difficulty of generic models in providing precise estimates, such as biophysiological properties of species and edaphoclimatic conditions (Goussanou et al., 2016). The inter-species variation in form factors of tropical tree stems (Larson, 1963; Silva et al., 1994) can make the generation of efficient generic equations difficult. Therefore, 
considering all species together in the development of generic models, and application of models to a region for which they were not developed may not be appropriate.

According to Vibrans et al. (20I5), due to peculiarities of tropical and subtropical forests, such as high species richness, floristic and structural heterogeneity, and a higher degree of natural conditions in general, equations specific for types and regions of forests may be necessary. Based on the results of the current study, we suggest that, for Amazonian forests, the equations must be even more restricted, in this case by species.

The heterogeneity of tropical forests is a determining factor for allometry of a species. The relationship between diameter and total tree height is directly related to environmental factors such as soil nutrients, climate, disturbance regime, successional stage, and topographic position, but also to tree species and various genetic factors (Feldpausch et al., 20l I). The differences in tree size (DBH and height), and consequently in stem volume between species has a direct effect on the performance of equations (Mate et al., 20I5). Considering this, the equations developed for more homogeneous datasets, such as those for tree species, can explain the variable of interest with greater precision, which justifies the results from this study.

In managed forests in the Amazon, greater precision in volumetric estimates signifies a reduction in the discrepancy between the volume authorized by the environmental agency in charge of forest monitoring and planning, and the real volume that is harvested. Furthermore, forest managers will be able to conduct operations and manage use of resources with greater assertiveness.

More precise estimates of commercial volume will also generate more reliable predictions of revenue from forestry operations, which could help to reduce errors in decisions taken with respect to planning for logging activities, including in the phase of negotiating the harvested wood in the market. As emphasized by Gama et al. (2017), the incorrect quantification of volumetric stocks will cause economic loss since efficient planning will be compromised.

\section{CONCLUSIONS}

In comparison with the generic equations (GEFMA and GEAPUs), the species-specific equations (SSEs) are more precise in estimating commercial volume of Amazonian species, and consequently are more appropriate for forest management in this region. Due to the high degree of uncertainty associated with measurements of commercial height in tropical forests, the species-specific equations obtained from single input Kopezky-Gehrhardt and Husch models represent the best option for estimating commercial volume of species managed in the TNF, besides being statistically valid for this purpose. The possibility of being able to measure commercial height more rigorously will make the use of double input equations a priority.

It can also be concluded that the compensation of under- and overestimates makes generic equations comparable to specific equations in terms of precision when applied to a population without stratification by species. Nevertheless, in the Amazon region there is great demand for estimates for individual species, which makes species-specific equations the most adequate option recommended for use in volume estimation.

Therefore, it is recommended that the use of generic equations be avoided if species-specific equations are available, which are essential in order to guarantee reliable predictions of volumetric stocks and revenues, thus contributing to decision-making and planning for forest management activities.

\section{ACKNOWLEDGMENTS}

This study was conducted with the support of the Brazilian Coordination for the Improvement of Higher Education Personnel (CAPES) - Project grant code 00I. The authors thank the Mixed Cooperative of the Tapajos National Forest (Coomflona), for providing the data that formed the base of this study, and Karla Mayara Almada Gomes (IBEF/ UFOPA) for creation of the map of the study location.

\section{REFERENCES}

AKINDELE, S. O.; LEMAY, V. M. Development of tree volume equations for common timber species in the tropical rain forest area of Nigeria. Forest Ecology and Management, v. 226, n. I-3, p. 4I-48, 2006.

BARRETO, W. F.; LEÃO, F. M.; MENEZES, M. C.; SOUZA, D. V. Equação de volume para apoio ao manejo comunitário de empreendimento florestal em Anapu, Pará. Pesquisa Florestal Brasileira, v. 34, n. 80, p. 2I-329. 2014.

BARROS, P. L. C.; SILVA JÚNIOR, A. T. Equação de volume para árvores de uma floresta tropical densa no município de Anapu, Oeste do estado do Pará, Amazônia oriental. Revista de Ciências Agrárias, v. 5I, n. 5I, p. II5-126, 2009.

BRANDEIS, T. J.; DELANEY, M.; PARRESOL, B. R.; ROYER, L. Development of equations for predicting Puerto Rican subtropical dry forest biomass and volume. Forest Ecology and Management, v. 233, n. I, p. I33-I42, 2006. 
BRASIL. Resolução Conama $n^{\circ}$ 406, de 02 de fevereiro de 2009. Estabelece parâmetros técnicos a serem adotados na elaboração, apresentação, avaliação técnica e execução de Plano de Manejo Florestal Sustentável-PMFS com fins madeireiros, para florestas nativas e suas formas de sucessão no bioma Amazônia. Brasília, 06 fev. 2009. Seção 26, p. 100.

CAMPOS, J. C. C.; LEITE, H. G. Mensuração florestal: Perguntas e respostas. Editora UFV, 2017. 636p.

COLPINI, C.; TRAVAGIN, D. P.; SOARES, T. S.; SILVA, V. S. M. Determinação do volume, do fator de forma e da porcentagem de casca de árvores individuais em uma Floresta Ombrófila Aberta na região noroeste do Mato Grosso. Acta Amazonica, v. 39, n. I, p. 97-104, 2009.

CYSNEIROS, V. C. Estratégias para Modelagem do Volume Comercial em Florestas Tropicais. 2016. II7 p. MSc dissertation, Universidade Federal do Paraná, Curitiba.

CYSNEIROS, V. C.; PELISSARI, A. L.; MACHADO, A. S.; FIGUEIREDO FILHO, A. SOUZA L. Modelos genéricos e específicos para estimativa do volume comercial em uma floresta sob concessão na Amazônia. Scientia Forestalis, v. 45 , n. II4, p. 295-304, 2017.

FELDPAUSCH, T.; BANIN, L.; PHILLIPS, O.; BAKER, T.; LEWIS, S.; QUESADA, C.; AFFUM-BAFFOE, K.; ARETS, E.; BERRY, N.; BIRD, M.; ET AL. Height-diameter allometry of tropical forest trees. Biogeosciences, v. 8, p. 1081 II06, 20II.

FINGER, C. A. G. Biometria Florestal. Universidade Federal de Santa Maria, 2006. 314p.

GAMA, J. R. V.; SOUZA, A. L.; VIEIRA, D. S.; LEITE, H. G. Equações de volume para uma floresta ombrófila aberta, município de Codó, estado do Maranhão. Revista Brasileira de Ciências Agrárias, v. I2, n. 4, p. 535-542, 2017.

GIMENEZ, B. O.; DANIELLI, F. E.; OLIVEIRA, C. K. A.; SANTOS J.; HIGUCHI, N. Equações volumétricas para espécies comerciais madeireiras do sul do estado de Roraima. Scientia Forestalis, v. 43, n. I06, p. 29I-30I, 2015.

GIMENEZ, B. O.; SANTOS, L. T.; GEBARA, J.; CELES, C. H. S.; DURGANTE, F. M.; LIMA, A. J. N.; SANTOS, J.; HIGUCHI, $\mathrm{N}$. Tree Climbing Techniques and Volume Equations for Eschweilera (Matá-Matá), a Hyperdominant Genus in the Amazon Forest. Forests, v. 8, n. I54, p. I-I I, 2017.

GOMES, K. M. A.; RIBEIRO, R. B. S.; GAMA, J. R. V.; ANDRADE, D. F. C. Eficiência na estimativa volumétrica de madeira na Floresta Nacional do Tapajós. Nativa, v. 6, n. 2, p. 170 176, 2018.

GONÇALVES, F. G.; SANTOS, J. R. Composição florística e estrutura de uma unidade de manejo florestal sustentável na Floresta Nacional do Tapajós, Pará. Acta Amazonica, v. 38, n. 2, p. 229-244, 2008.
GOUSSANOU, C. A.; GUENDEHOU, S.; ASSOGBADJO, A. E.; KAIRE, M.; SINSIN, B.; CUNI-SANCHEZ, A. Specific and generic stem biomass and volume models of tree species in a West African tropical semideciduous forest. Silva Fennica, v. 50, n. 2, p. I-22, 2016.

GUENDEHOU, G. H. S.; LEHTONEN, A.; MOUDACHIROU, M.; MÄKIPÄÄ, R.; SINSIN, B. Stem biomass and volume models of selected tropical tree species in West Africa. Southern Forests, v. 74, n. 2, p. 77-88, 2012.

HEINSDIJK, D.; BASTOS, A. M. Inventários Florestais na Amazônia. Boletim do Serviço Florestal $N^{\circ}$ 6. Setor de Inventários Florestais, Ministério da Agricultura. 1963. 100p.

HIRAMATSU, N. A. Equações de Volume Comercial para Espécies Nativas na Região do Vale do Jari, Amazônia Oriental. 2008. 107p. MSc dissertation, Universidade Federal do Paraná, Curitiba.

KACHAMBA, D. J.; EID, T. Total tree, merchantable stem and branch volume models for miombo woodlands of Malawi. Southern Forests, v. 78, n. I, p. I-II, 2016.

KORA, S. A.; GUENDEHOU, G. H. S.; GOUSSANOU, C. A.; ASSOGBADJO, A. E.; SINSIN, B. Allometric equations from a non-destructive approach for biomass prediction in natural forest and plantation in West Africa. Southern Forests, v. 8I, p. I-I2, 2018.

KRAINOVIC, P.; ALMEIDA, D.; SAMPAIO, P. New Allometric Equations to Support Sustainable Plantation Management of Rosewood (Aniba rosaeodora Ducke) in the Central Amazon. Forests, v. 8, n. 9, p. I-28, 2017.

LARSON, P. R. Stem form development of forest trees. Forest Science, v. 9, a000I, 1963.

LIMA, R. B.; APARÍCIO, P. S.; FERREIRA, R. L. C.; SILVA, W. C.; GUEDES, M. C.; OLIVEIRA, C. P.; SILVA, D. A. S.; BATISTA, A. P. B. Volumetria e classificação da capacidade produtiva para Mora paraensis (Ducke) no estuário amapaense. Scientia Forestalis, v. 42, n. I0I, p. I4I-I54, 2014.

MACHADO, S. A.; NASCIMENTO, R. G. M.;AUGUSTYNCZIK, A. L. D.; SILVA, L. C. R.; FIGURA, M. A.; PEREIRA, E. M.; TÉO, S. J. Comportamento da relação hipsométrica de Araucaria angustifolia no capão da Engenharia Florestal da UFPR. Pesquisa Florestal Brasileira, n.56, p. 5-16, 2008.

MCROBERTS, R. E, WESTFALL, J. Effects of uncertainty in model predictions of individual tree volume on large area volume estimates. Forest Science, v. 60, n. I, p. 34-42, 2014.

MATE, R.; JOHANSSON, T.; SITOE, A. Stem Volume Equations for Valuable Timber Species in Mozambique. Journal of Sustainable Forestry, v. 34, p. 787-806, 2015.

MAUYA, E. W.; MUGASHA, W. A.; ZAHABU, E.; BOLLANDSÅS, O. B.; EID, T. Models for estimation of tree volume in the miombo woodlands of Tanzania. Southern Forests, v. 76, n. 4, p. 209-219, 2014. 
R CORE TEAM. R: A Language and Environment for Statistical Computing. Vienna: $R$ Foundation for Statistical Computing, Vienna, Austria, 2019. Available at: https://www.R-project.org. Accessed in: Set 17th 2019.

RIBEIRO, R. B. S.; GAMA, J. R. V.; MELO, L. O. Seccionamento para cubagem e escolha de equações de volume para a Floresta Nacional do Tapajós. Cerne, v. 20, n. 4, p. 605-6I2, 2014.

ROLIM, S. G.; COUTO, H. T. Z.; JESUS, R. M.; FRANÇA, J. T. Modelos volumétricos para a Floresta Nacional do Tapirapé-Aquirí, Serra dos Carajás (PA). Acta Amazonica, v. 36, n. I, p. I07-II4, 2006.

SANTOS, M. F.; FIGUEIREDO FILHO, A.; GAMA, J. R. V.; RETSLAFF, F. A. S.; COSTA, D. L.; GOMES, K. M. A.; CRUZ, G. S.; ALMEIDA, B. R. S. Eficiência de equações volumétricas para Manilkara spp. em floresta manejada na Amazônia Oriental. Nativa, v. 7, n. 5, p. 621-628, 2019.

SEGURA, M.; KANNINEN, M. Allometric models for tree volume and total aboveground biomass in a tropical humid forest in Costa Rica. Biotropica, v. 37, n. I, p. 2-8, 2005.

SILVA, J. A. A.; BORDERS, B. E.; BRISTER, G. H. Estimating tree volume using a new form factor. Commonweal Forestry Review, v. 73, n. I, p. 14-17, 1994.
SILVA, E. M.; SANTANA, A. C. Modelos de regressão para estimação do volume de árvores comerciais, em florestas de Paragominas. Ceres, v. 6I, p. 63I-636, 2014.

SOARES, C. P. B.; MARTINS, F. B.; LEITE JUNIOR, H. U.; SILVA, G. F.; FIGUEIREDO, L. T. M. Equações hipsométricas, volumétricas e de Taper para onze espécies nativas. Árvore, v. 35, n. 5, p. 1039-105I, 2011.

THAINES, F;; BRAZ, E. M.; MATTOS, P. P.; THAINES, A. A. R. Equações para estimativa de volume de madeira para a região da bacia do Rio Ituxi, Lábrea, AM. Pesquisa Florestal Brasileira, v. 30, n. 64, p. 283-289, 2010.

TONINI, H.; BORGES, R. A. Equação de volume para espécies comerciais em Floresta Ombrófila Densa no sul de Roraima. Pesquisa Florestal Brasileira, v. 35, n. 82, p. III-II7, 2015.

TSEGA, M.; GUADIE, A.; TEFFERA, Z. L.; BELAYNEH, Y.; NIU, D. Development and validation of a stem volume equation for Cupressus lusitanica in Gergeda Forest, Ethiopia. Southern Forests, v. 8I, p. I-6, 2018.

VIBRANS, A. C.; MOSER, P.; OLIVEIRA, L. Z.; MAÇANEIRO, J. P. Generic and specific stem volume models for three subtropical forest types in southern Brazil. Annals of Forest Science, v. 72, p. 865-874, 2015. 